\title{
Meningkatkan Kompetensi Guru SMPN 2 Wera Dalam Penyusunan Proposal Penelitian Tindakan Kelas (PTK) Melalui Bimbingan Kelompok Berbasis MGMP Tahun 2017/2018 di SMPN 2 Wera
}

\author{
Andi Irawan \\ Kepala SMPN 2 Wera.
}

\begin{abstract}
Abstrak; kebanyakan guru SMPN 2 Wera belum mau melakukan Penelitian Tindakan Kelas (PTK), penyebabnya karena beban mengajar banyak yang berdampak kurang termotivasinya dalam penulisan karya tulis ilmiah, solusinya adalah diadakan pembimbingan secara berkelompok. Penelitian ini bertujuan untuk mengetahui sejauhmana efektifitas penerapan pembimbingan kelompok dalam upaya meningkatkan kompetensi guru SMPN 2 Wera dalam penyusunan proposal PTK yang bermanfaat bagi guru dalam peningkatan profesionalisme guru dalam tugas sehari-hari. Dari berbagai kajian teori maka hipotesis tindakan pada penulisan ini adalah : Pelaksanaan bimbingan kelompok berbasis MGMP di SMPN 2 Wera dapat meningkatkan kompetensi guru SMPN 2 Wera dalam penyusunan proposal PTK. Penelitian ini dipusatkan di SMPN 2 Wera sebagai tempat diselenggarakannya MGMP. Dalam pelaksanaan Penelitian Tindakan Sekolah (PTS) ini sebanyak dua siklus, dimana masing-masing siklus terdapat empat tahapan yaitu perencanaan, pelaksanaan, observasi dan refleksi. Indikator keberhasilan dalam penelitian ini adalah Kompetensi Guru SMPN 2 Wera adalah : jika $\geq 10 \%$ dari jumlah peserta pembimbingan telah memperleh nilai rata-rata $\geq 85,00$. Hasil Penelitian Tindakan Sekolah (PTS) pada siklus II diperoleh data sebagai berikut ; 1) observasi pengawas $(4,22), 2$ ) observasi guru $(4,14), 3)$ hasil kerja secara klasikal $(84,02)$. Indikator keberhasilan telah terlampaui Penelitian Tindakan Sekolah (PTS) dinyatakan berhasil, dan penelitian dihentikan pada siklus II. Bimbingan kelompok sangat efektif dalam upaya meningkatkan kompetensi guru SMPN 2 Wera dalam penyusunan proposal PTK karena $90 \%$ dari jumlah peserta sebanyak 35 (tiga puluh lima) orang guru telah berhasil menyusun proposal PTK sesuai harapan. Disarankan kepala sekolah sejawat untuk melakukan kegiatan pembimbingan bagi guru yang menjadi tanggungjawabnya dalam upaya peningkatan kompetensi dalam kegiatan pengembangan keprofesian berkelanjutan (PKB).
\end{abstract}

Kata Kunci : Bimbingan Kelompok-kompetensi guru SMPN 2 Wera.

\section{PENDAHULUAN}

Kondisi nyata yang dihadapi oleh kebanyakan guru SMPN 2 Wera, masih banyak ditemukan bahwa guru belum memiliki kemampuan dan kemauan menyusun proposal Penelitian Tindakan Kelas (PTK) apalagi melakukan. Alasan konvensional yang sering ditemukan oleh kebanyakan guru SMPN 2 Wera adalah ; 1) jam mengajar banyak sehingga tidak ada waktu untuk membuat proposal/melaksanakan Penelitian Tindakan Kelas (PTK), 2) sibuk membuat perangkat pembelajaran , 3) sibuk mengoreksi hasil kerja siswa, dan masih banyak lagi alasan-alasan konvensional yang kurang masuk akal.

Faktor penyebab terjadinya kondisi di atas antara lain, kurang pedulinya kepala sekolah selaku peneliti terhadap guru-guru yang kurang berminat mempelajari apa itu PTK, bagaimana PTK, dan untuk apa harus ber PTK. Penyebab yang lain berasal dari kebanyakan guru SMPN 2 Wera yang memang enggan berusaha untuk mempelajari apa itu PTK, bagaimana PTK, dan untuk apa harus ber PTK. Kedua penyebab inilah yang menjadi faktor penyebab utama sehingga terjadi kondisi seperti yang telah dipaparkan di 
atas. Kepala sekolah selaku peneliti sifatnya hanya menunggu guru yang ingin berkonsultasi tentang PTK, tidak pernah menjemput bola artinya proaktif terhadap permasalahan guru SMPN 2 Wera yang menjadi binaannya. Dari pihak guru juga demikian, kebanyakan kurang peduli terhadap PTK, pendapat guru tidak naik pangkat juga tidak apaapa.

Banyak solusi yang bisa dilakukan dalam upaya meningkatkan kompetensi guru SMPN 2 Wera dalam penyusunan proposal Penelitian Tindakan Kelas (PTK), diantaranya adalah melalui bimbingan kelompok. Pelaksanaan bimbingan kelompok ini bisa dilaksanakan melalui kegiatan Musyawarah Guru Mata Pelajaran (MGMP) khusus dalam penyusunan proposal PTK. Melalui kegiatan MGMP inilah diharapakan kepala sekolah selaku peneliti dapat melakukan bimbingan terhadap guru-guru SMPN 2 Wera dalam penyusunan proposal Penelitian Tindakan kelas (PTK) melalui tindakan nyata, terencana, terprogram dan terpantau secara langsung upaya-upaya meningkatkan kompetensi khususnya tata cara penyusunan proposal Penelitian Tindakan Kelas (PTK). Adapun keunggulan pelaksanaan bimbingan kelompok antara lain: 1)pembelajaran yang sulit bisa menjadi mudah, 2) bisa memecahkan permasalahan secara bersama-sama, 3) hasil kerja lebih berkualitas bila dibandingkan dengan pekerjaan sendirian, 4) menjalin tali silaturrahim dan kekeluargaan yang tinggi.

Untuk membuktikan hal tersebut di atas maka perlu diadakan Penelitian Tindakan Sekolah (PTS) dalam upaya meningkatkan kompetensi Guru SMPN 2 Wera dalam penyusunan proposal Penelitian Tindakan Kelas (PTK) yang dilakukan melalui kegiatan pembimbingan kelompok kecil dalam wadah MGMP SMPN 2 Wera. Alasan bimbingan melalui wadah MGMP antara lain: 1) permasalahan yang berat bisa diselesaikan secara bersama-sama, 2) bisa saling tukar pengalaman dan tukar pendapat tentang sesuatu yang dialami di sekolah yang berbeda/di kelas yang berbeda, 3) menumbuh kembangkan nilai percaya diri, 4) membuat semangat bekerja/motivasi kerja tinggi, 5) bisa merubah mindset guru dari dalam pola berfikir, bertindak, dan mampu berkarya sesuai dengan mata pelajaran yang diampunya. Adapun judul Penelitian Tindakan Sekolah ini adalah : "Meningkatkan Kompetensi Guru SMPN 2 Wera dalam Penyusunan Proposal Penelitian Tindakan Kelas (PTK) Melalui Bimbingan Kelompok Berbasis MGMP Tahun 2017/2018". Tujuan penelitian adalah untuk mengetahui efektifitas pelaksanaan pembimbingan kelompok berbasis MGMP dalam upaya meningkatkan kompetensi guru SMPN 2 Wera dalam penyusunan proposal Penelitian Tindakan Kelas (PTK) semester dua tahun 2017/2018.

\section{KAJIAN PUSTAKA Kerangka Teoritis Kompetensi}

Menurut

Uzer Usman

"Kompetensi merupakan perilaku yang rasional untuk mencapai tujun yang diisyaratkan sesuai kondisi yang diharapkan. Adapun kompetensi guru (teacher competency) merupakan kemampuan seorang guru dalam melaksanakan kewajiban-kewajiban secara bertanggung jawab dan layak (2001:14)". Dalam Kamus Besar Bahasa Indonesia, "Kompetensi diartikan suatu kewenangan (kekuasaan) untuk menentukan (merumuskan sesuatu) (584)".

Dalam Penelitian Tindakan Sekolah (PTS) ini yang dimaksud kompetensi adalah kemampuan guruguru SMPN 2 Wera dalam penyusunan proposal Penelitian Tindakan Kelas (PTK) yang baik dan benar berdasarkan peraturan yang berlaku dan diharapkan dapat melaksanakan dan menyusun 
laporan Penelitian Tindakan Kelas (PTK) secara lengkap, rinci, terukur, dan memenuhi kriteria yang APIK (Asli, Perlu, Ilmuah, dan Konsisten).

\section{Proposal}

Nana Sudjana, dalam bukunya yang berjudul "Penelitian Tindakan Kekepala sekolahan", mendifinisikan pengertian proposal penelitian atau usulan penelitian dapat juga diartikan sebagai suatu pernyataan tertulis mengenai rencana dan rancangan kegiatan penelitian secara keseluruhan (2009:27). Dalam Kamus Besar Bahasa Indonesia, proposal artinya rencana yang dituangkan dibentuk rancangan kerja (899).

Dalam Penelitian Tindakan Sekolah (PTS) ini, yang dimaksud dengan proposal adalah suatu pernyataan tertulis mengenai rencana tindakan dalam upaya meningkatkan kompetensi guru SMPN 2 Wera dalam penyusunan proposal Penelitian Tindakan Kelas (PTK) melalui bimbingan kelompok berbasis MGMP.

\section{Penelitian}

"Penelitian (Riset, Research) merupakan penyelidikan suatu masalah secara sitimatis, kritis, ilmiah dan lebih formal. Penelitian merupakan kegiatan yang dilakukan dengan menggunakan logika proses berfikir eksplisit (artinya, setiap langkahnya dilakukan secara terbuka sehingga dapat dikaji kembali, baik oleh yang bersangkutan maupun oleh orang lain) dan informasinya dikumpulkan secara sistimatis dan objektif “. (Suharjono, 2006:53)

Pendapat pakar yang lain mengatakan bahwa ; penelitian merupakan kegiatan mencermati suatu objek, dengan menggunakan aturan tertentu untuk memperoleh informasi yang bermanfaat (Ariskunto.S, 2006:53).

Dalam Penelitian Tindakan

Sekolah (PTS) ini, penelitian difokuskan pada upaya meningkatkan kompetensi guru SMPN 2 Wera dalam penyusunan proposal Penelitian Tindakan Kelas
(PTK) melalui kegiatan Musyawarah Guru Mata Pelajaran (MGMP)

Penelitian Tindakan Kelas (Classroom Action Research).

Menurut pendapat salah satu pakar pendidikan menyatakan ; "Penelitian yang dilakukan oleh guru, bekerjasama dengan peneliti (atau dilakukan oleh guru sendiri yang juga bertindak sebagai peneliti)di kelas atau disekolah tempat ia mengajar dengan penekanan atau penyempurnaan atau peningkatan proses dan praktik pembelajaran (Supandi, 2006:57)". Pendapat lain mendifinisikan : "Penelitian Tindakan Kelas adalah penelitian yang menkombinasikan prosedur penelitian dengan tindakan substantive, suatu tindakan yang dilakukan dalam disiplin inquiri, atau suatu usaha seseorang untuk memahami apa yang sedang terjadi, sambil terlibat dalam sebuah proses perbaikan dan perubahan (Wiriatmodjo, 2007:11)".

Dalam penelitian ini, Penelitian Tindakan Kelas (PTK) adalah penelitian yang dilakukan di kelas oleh 35 (tiga puluh lima) orang guru peserta pembimbingan penyusunan proposal Penelitian Tindakan Kelas (PTK).

\section{Penelitian Tindakan Sekolah (PTS)}

Penelitian tindakan banyak dilakukan baik oleh guru mupun kepala sekolah. Bila dilakukan guru umum disebut sebagai Penelitian Tindakan Kelas dan disingkat dengan PTK, sedangkan bila dilakukan oleh kepala sekolah sekolah disebut sebagai Penelitian Tindakan Sekolah atau disingkat dengan sebutan PTS (Depdiknas, 2008:36). Prinsip penelitian tindakan yaitu ; 1) kegiatan nyata dalam situasi rutin, 2) adanya kesadaran diri untuk memperbaiki kinerja, 3) SWOT sebagai dasar berpijak, 4) upaya empiris dan sistimatik, 5) ikuti prinsip SMART dalam perencanaan (Arikunto.S, 2006:68).

Dalam penelitian ini yang dimaksud Penelitian Tindakan Sekolah 
(PTS) adalah penelitian tindakan yang dilakukan oleh kepala sekolah dalam upaya meningkatkan kompetensi guru SMPN 2 Wera dalam penyusunan proposal Penelitian Tindakan Kelas (PTK) melalaui bimbingan kelompok berbasis Musyawarah Guru Mata Pelajaran (MGMP). Adapun sistimatika penyusunan proposal disamakan dengan sistimatika penyusunan laporan Penelitian Tindakan Kelas (PTK), dengan alasan untuk mempercepat dan memudahkan dalam penyusunan laporan hasil Penelitian Tindakan Kelas (PTK).

Sistimatika proposal/laporan PTK adalah sebagai berikut :

BAB I : Pendahuluan, yang kegiatannya meliputi ; latar belakang, rumusan masalah, cara pemecahan masalah, tujuan penelitian, dan manfaat penelitian .

BAB II : Kajian pustaka yang isinya meliputi ; kerangka empiris, kerangka teoritis, kerangka konseptual dan hipotesis tindakan.

BAB III : Metode penelitian, yang isinya meliputi ; setting penelitian, sumber data, siklus penelitian (refleksi awal, perencanaan, pelaksanaan pengamatan/observasi dan refleksi), teknik pengumpulan data, proses pengumpulan data, analisis data, indikator keberhasilan/indikator kinerja.

\section{Bimbingan Kelompok}

Teknik pendekatan secara
kelompok, yaitu bimbingan yang dilaksanakan secara kelompok terhadap sejumlah individu sekaligus sehingga beberapa orang atau individu sekaligus dapat menerima bimbingan yang dimaksudkan (Hartinah.S, 2009:4). Pendapat lain mengatakan bahwa kelompok adalah suatu unit yang terdiri atas dua orang atau lebih dan berbeda pada satu keompok, untuk satu tujuan dan mereka mempertimbangkan bahwa kontaknya mempunyai arti (Mills dalam Iskandar, 1999:120). Selanjutnya ada juga pendapat ahli lainnya mengatakan kelompok adalah sejumlah orang yang berinteraksi dengan sesama dan interaksi (proses interaksi) membedakan bentuk kelompok. Kelompok bersama dengan kelompok yang lainnya (Hartinah. S, 2009:244).

Dalam Penelitian Tindakan Sekolah (PTS) ini yang dimaksud dengan bimbingan kelompok ini adalah ; penyusunan proposal Penelitian Tindakan Kelas (PTK) yang diikuti oleh 35 (tiga puluh lima) orang guru SMPN 2 Wera yang dilakukan melalui bimbingan kelompok, dimana setiap kelompoknya beranggotakan 12 dan 11 orang guru yang dilaksanakan melalui kegiatan Musyawarah Guru Mata Pelajaran (MGMP).

MGMP

Musyawarah Guru Mata Pelajaran sama halnya dengan $\mathrm{KKG}$, merupakan suatu organisasi guru yang dibentuk untuk menjadi forum komunikasi yang bertujuan untuk memecahkan masalah yang dihadapi guru dalam pelaksanaan tugasnya sehari-hari di lapangan. MGMP berada di tingkat sekolah lanjutan, baik SLTP maupun SLTA.

Musyawah Guru Mata Pelajaran, awalnya disebut Musyawarah Guru Bidang Studi, adalah suatu organisasi profesi guru yang bersifat non struktural yang dibentuk oleh guru-guru di Sekolah Menengah (SLTP atau SLTA) di suatu wilayah sebagai wahana untuk saling bertukaran pengalaman guna meningkatkan kemampuan guru dan memperbaiki kualitas pembelajaran. Selain ditingkat komisariat, MGMP pun memilki wadah yang lebih luas ditingkat kabupaten atau kota. Hal ini untuk lebih mencakup permasalahan-permasalahan yang ada pada guru secara meluas sehingga kesenjangan yang ada pada guru lebih kecil, dan mereka dapat lebih mengetahui permasalahan dan solusinya dari hasil pertemuan kelompok kerja tersebut secara menyeluruh.

Undang-undang RI Nomor 14 tahun 2005 tentang Guru dan Dosen mempersyaratkan guru untuk: 1) 
Memiliki kualifikasi akademik minimum S1/D4, 2)Memiliki kompetensi sebagai agen pembelajaran yaitu kompetensi pedagogik,kepribadian,sosial,dan

profesional, 3) Memiliki sertifikat pendidik. Dengan berlakunya undangundang ini diharapkan memberikan suatu kesempatan yang tepat bagi guru untuk meningkatkan profesionalismenya melalui pelatihan,penulisan karya ilmiah,pertemuan di Musyawarah Guru Mata Pelajaran (MGMP).Dengan demikian MGMP memiliki peran penting dalam mendukung pengembangan profesional guru.

Sebagaimana kita ketahui, MGMP merupakan forum atau wadah profesionalisme guru mata pelajaran yang berada pada suatu wilayah kabupaten/kota/kecamatan/sanggar/gugus sekolah. Ruang lingkupnya meliputi guru mata pelajaran pada tingkat SMP,SMA,dan SMK Negeri dan Swasta,baik yang berstatus PNS maupun swasta. Prinsip kerjanya adalah cerminan kegiatan "dari,oleh,dan untuk guru"dari semua sekolah. Atas dasar ini,maka MGMP merupakan organisasi nonstruktural yang bersifat mandiri,berasaskan kekeluargaan,dan tidak mempunyai hubungan hierarkis dengan lembaga lain.

Dalam hal ini adapun tujuan diselenggarakanya MGMP,yaitu: 1) Untuk memotivasi guru guna meningkatkan kemampuan dan keterampilan dalam merncanakan, melaksanakan, dan membuat evaluasi program pembelajaran dalam rangka meningkatkan keyakinan diri sebgai guru profesional, 2) untuk meningkatkan kemampuan dan kemahiran guru dalam melaksanakan pembelajaran sehingga dapat menunjang usaha peningkatan dan pemerataan mutu pendidikan, 3) Untuk mendiskusikan permasalahan yang dihadapi dan dialami oleh guru dalam melaksanakan tugas sehari-haridan mencari solusi alternatif pemecahanya sesuai dengan karakteristik mata pelajaran masing-masing,guru,kondisi sekolah,dan lingkunganya, 4) Untuk membantu guru memperoleh informasi teknis edukatif yang berkaitan dengan kegiatan ilmu pengetahuan dan teknologi,kegiatan

kurikulum,metodologi,dan sistem pengujian yang sesuai dengan mata pelajaran yang bersangkutan, 5) Untuk saling berbagi informasi dan pengalaman dari hasil lokakarya,simposium,seminar,diklat,class room action research,referensi,dan lainlain kegiatan profesional yang di bahas bersama-sama.

\section{Kerangka Konseptual}

Gambar hubungan antara variabel tindakan dengan variabel harapan dapat dijelaskan sebagai berikut : 1) Pelaksanaan bimbingan kelompok yang dilakukan pada saat guru mengadakan kegiatan Musyawarah Guru Mata Pelajaran (MGMP) di bagi menjadi 3 (tiga) kelompok besar, masing-masing adalah kelompok I yang beranggotakan terdiri atas 12 (dua belas) orang, kelompok ke II dengan jumlah anggota 11 (sebelas) orang dan kelompok III (tiga) beranggotakan 12 (dua belas) orang.

Penelitian Tindakan Kelas (PTK) ini direncanakan terdiri atas 2 (dua) siklus, setiap siklusnya minimal satu kali tatap muka (akan lebih baik jika setiap siklus 2-3 kali tatap muka/sesuai kebutuhan). Bila pada siklus II indikator keberhasilan/indikator kinerja telah tercapai, maka Penelitian Tindakan Kelas (PTK) dihentikan, akan tetapi jika indikator keberhasilanbelum tercapai, maka Penelitian Tindakan Kelas (PTK) dilanjutkan ke siklus berikutnya sampai indikator keberhasilan telah tercapai secara riil sesuai hasil analisa data senyatanya.

\section{METODE PENELITIAN}

Penelitian Tindakan Sekolah (PTS) ini dilaksanakan di SMPN 2 Wera dengan jumlah peserta 35 (tiga puluh lima) guru yang terdiri atas laki-laki 11 
orang dan perempuan 24 orang yang semuanya memerlukan pembimbingan dalam penyusunan proposal PTK.

- Waktu Penelitian : dilaksanakan dari pukul $08.00 \mathrm{~s} / \mathrm{d} 14.30 \mathrm{Wita}$

- Lama Penelitian : 4 bulan (Januari, Februari, Maret, dan April 2015)

- Subyek Penelitian : 35 (tiga puluh lima) orang guru SMPN 2 Wera dokumen yang telah di buat oleh kepala sekolah selaku peneliti

- Data hasil observaasi kegiatan kepala sekolah selama proses pembimbingan diambil pada saat melakukan pembimbingan berkelompok

- Data hasil observasi guru diambil pada saat guru melakukan diskusi membahas penyusunan proposal PTK

- Obyek Penelitian : 1) Kompetensi Guru SMPNberbasis MGMP

2 Wera dalam penyusunan Proposal PenelieianData hasil penyusunan draf proposal Tindakan Kelas (PTK); 2) Bimbingan kelompokPenelitian Tindakan Kelas (PTK) berbasis MGMP

Varibel Input : 1) Bagaimana kesiapan kepala sekolah dalam merencanakan pembimbingan kelompok berbasis MGMP, 2) Bagaimana kesiapan Guru SMPN 2 Wera dalam penyusunan proposal Penelitian Tindakan Kelas (PTK)

Variabel Proses : 1) Bagaimana proses pelaksanaan pembimbingan kelompok berbasis MGMP, 2) Bagaimana kemampuan Guru SMPN 2 Wera dalam penyusunan proposal PTK selama MGMP

Variabel Output : 1) Bagaimana hasil pembimbingan kelompok bebabasis MGMP, 2) Seberapa jauh kompetensi guru dalam penyusunan proposal Penelitian Tindakan Kelas (PTK)

Sumber Data : Yang menjadi sumber data dalam Penelitian Tindakan Sekolah (PTS)ini adalah guru SMPN 2 Wera sebanyak 35 (tiga puluh lima) guru yang memerlukan pembimbingan dalam penyusunan proposal PTK.

- Data yang berasal dari kepala sekolah/peneliti meliputi : 1) Rencana Pelaksanaan Pembimbingan (RPP), 2) Hasil obsevasi kepala sekolah/peneliti

- Data yang berasal dari guru: 1) Hasil observasi guru, 2) Hasil penyusunan proposal Penelitian Tindakan Kelas (PTK)

- Data Rencana Pelaksanaan Pembimbingan (RPP), diambil dari diambil dari dokumen draf proposal secara individual

Untuk melakukan analisis data dapat dilakukan melalui analisis diskriptif kualitatif melalui pendataan analisis dan pembahasan terhadap data yang diperoleh dengan mencocokkan tingkat keoptimalan terhadap indikator keberhasilan/indikator kinerja.

Untuk mendapatkan gambaran tahapan kegiatan tiap-tiap siklus dapat digambarkan sebagai berikut :

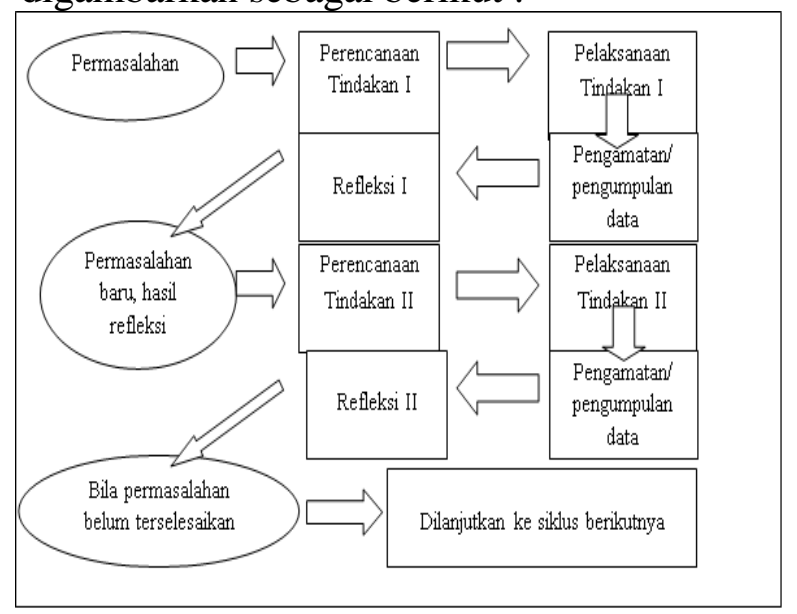

Gambar 3.1 : Skenario Tindakan

\section{Siklus Tindakan SIKLUS I}

\section{Tahap I : Perencanaan Tindakan}

- Penyusunan Rencana Pelaksanaan Pembimbngan (RPP)

- Menyiapkan alat dan sumber bahan yang diperlukan dalam penelitian

- Menyusun instrumen observasi kepala sekolah dan instrumen observasi guru 
- Menyusun pedoman analisis hasil observasi

- Menyusun jadwal kegiatan pembimbingan

Tahap II : Pelaksanaan Tindakan

- Peneliti menyapaikan materi tenatang Penelitian Tindakan Kelas (PTK)

- Tanya jawab sekitar materi proposal Penelitian Tindakan Kelas (PTK)

- Kerja kelompok ; praktek penyusunan proposal Penelitian Tindakan Kelas (PTK)

- Bimbingan secara berkelompok maupun secara perorangan dalam kelompok

- Memberikan solusi terhadap permasalahan dalam penyusunan proposal Penelitian Tindakan Kelas (PTK)

- Memberikan penguatan/reward.

Tahap III : Pengamatan Pengumpulan Data

- Mengamati kegiatan kepala sekolah/peneliti oleh pengawas sebagai pembimbing

- Mengamati kegiatan diskusi kelompok/kerja kelompok

- Mengamati dan menganalisis hasil observasi

\section{Tahap IV : Refleksi}

- Renungan/pemikiran atas data hasil observasi/pengamatan

- Perbaikan dan penyempurnaan jenis tindakan

- Memberi saran perbaikan dan solusinya

- Memberikan penguatan/reward atas hasil observasi

- Menyusun rencana tindak lanjut/rekomendasi atas hasil capaian pada siklus yang dilakukan.

\section{SIKLUS II}

Pada dasarnya semua jenis tindakan yang dilakukan pada siklus II ini sama dengan siklus I, hanya saja terdapat penyemppurnaan/perbaikan sesuai dengan harapan. Untuk mendapatkan gambaran nyata tentang kegiatan siklus II dapat diuraikan sebagai berikut :

- Proses pembimbingan kelompok dinyatakan telah berhasil jika skor rata-rata yang diperoleh oleh pembimbing (kepala sekolah) maupun terbimbing (Guru SMPN 2 Wera) minimal $\geq 4,00$ (empat koma nol/kategori baik).

- Kompetensi guru SMP Negeri 16 dalam penyusunan proposal Penelitian Tindakan Kelas (PTK) dinyatakan telah meningkat jika $\geq 10$ $\%$ dari jumlah peserta pembimbingan telah memperoleh nilai rata-rata $\geq$ 85,00

\section{PEMBAHASAN \\ DESKRIPSI SIKLUS I}

Perencanaan Tindakan

$\begin{array}{cr}\text { Kepala sekolah selaku peneliti } \\ \text { menyusun } & \text { Rencana }\end{array}$ Pembimbingan (RPP) dengan memfokuskan pada skenario pelaksanaan pembimbingan yang kontekstual dan melibatkan aktifitas,kreatifitas, serta efektifitas seluruh guru SMPN 2 Wera sebagai peserta pembimbingan penyusunan proposal Penelitian Tindakan Kelas (PTK). Selanjutnya kepala sekolah selaku peneliti menyiapkan alat-alat seperti laptop, LCD, layar, dan semua bahan yang diperlukan oleh peserta selama pelaksanaan pembimbingan disiapkan dengan baik. Kegiatan penyusunan instrumen observasi kepala sekolah dan instrumen observasi guru difokuskan pada keterlaksanaan penyusunan proposal. Pelaksanaan Tindakan

Selama proses penyampaian materi tentang penyusunan proposal Penelitian Tindakan Kelas (PTK), yang pelaksanaannya pada Bab I. Pendahuluan, kepala sekolah selaku peneliti memberikan contoh langsungtentang 
bagaimana membuat latar belakang masalah yang berujung munculnya judul penelitian, bagaimana membuat rumusan masalah dan pemecahannya, serta bagaimana membuat tujuan dan manfaat penelitian. Sedangkan untuk kajian pustaka dan metode penelitian cukup dijelaskan dan penyusunannya dijadikan tugas mandiri untuk dikerjakan diluar jam pembimbingan. Bagi guru yang memerlukan bimbingan dilaksanakan secara individual bisa pada jam kerja maupun diluar jam kerja.

Kegiatan dilanjutkan dengan kerja kelompok dimana peserta yang berjumlah 35 (tiga puluh lima) orang dibagi menjadi 3 (tiga) kelompok besar, masingmasing kelompok beranggotakan 11-12 orang, yang terdiri dari 12 (dua belas) orang guru kelas VII, 11 (sebelas) orang guru kelas VIII, dan 12 (dua belas) orang guru kelas IX. Selama proses diskusi kelompok yang membahas tentang bagaimana menyusun propsal PTK yang baik dan benar sesuai dengan prosedur yang berlaku. Kepala sekolah selaku peneliti berkeliling dari satu kelompok ke kelompok lain untuk memberikan bimbingan teknis dan memfasilitasi segala kejadian yang memerlukan pembinaan.

Pada akhir pembimbingan secara berkelompok, kepala sekolah memberikan tugas (PR) untuk dikerjakan di luar jam pembimbingan diharapkan waktu yang ditentukan semua peserta pembimbingan sudah selesai menyusun proposal PTK.

\section{Observasi / Pengamatan dan Pengumpulan Data}

Data hasil observasi kepala sekolah yang dilakukan oleh observer yaitu pengawas pembimbing, diperoleh skor rata-rata sebesar 3,56, Observasi guru memperoleh skor rata-rata sebesar 3,62 dan hasil kerja secara individual penyusunan proposal Penelitian Tindakan Kelas (PTK) yang dikerjakan dalam proses pembimbingan selama siklus I yang dilanjutkan diluar pembimbingan sebagai tugas ( PR ) diperoleh nilai ratarata sebesar 78,87 .

\section{Refleksi}

Pada akhir pembimbingan kepala sekolah selaku peneliti merenung atas hasil perolehan data pada saat pengamatan dimana kepala sekolah selaku peneliti memperoleh skor rata-rata 3,56, sedangkan hasil pengamatan kegiatan selama bekerjasama dalam kelompok kecil diperoleh skor rata-rata 3,62 dan hasil akhir dari kerja individual secara klasikal baru tercapai dan nilai rata-rata klasikal 78,87.

Perolehan skor dan nilai pada siklus I masih jauh di bawah rata-rata indikator kinerja yang diharapkan yaitu $\geq$ 4,00 dan nilai rata-rata individual $\geq$ 85,00 , maka kepala sekolah selaku peneliti berupaya untuk memperbaiki dan menyempurnakan atas kesalahankesalahan dan kekurangan yang dilakukan oleh peneliti maupun guru selama proses pembimbingan pada siklus I.

Saran perbaikan dan solusi pada siklus I ini antara lain : 1) cara membimbing peneliti dalam penyusunan proposal Penelitian Tindakan Kelas (PTK) terkesan terlalu tergesa-gesa, solusinya adalah pada siklus berikutnya akan dilakukan lebih berhati-hati dan lebih tenang agar peserta pembimbingan/guru dapat memahami dan mampu berbuat sesuai harapan, 2) cara guru bekerja latihan menyusun draf proposal Penelitian Tindakan Kelas (PTK) masih terkesan lamban, santai dan kurang meperhatikan petunjuk yang diberikan oleh kepala sekolah selaku peneliti. Solusi yang dilakukan pada siklus ke-2 guru akan lebih bersemangat mengikuti pembimbingan secara berkelompok dalam penyusunan proposal Penelitian Tindakan Kelas (PTK).

Langkah selanjutnya peneliti menyusun rencana tindak lanjut : 1) penelitian dilakukan pada siklus berikutnya, 2) dalam pelaksanaan pembimbingan penyusunan proposal 
Penelitian Tindakan Kelas (PTK) pada siklus berikutnya harus lebih baik dan lebih terencana secara matang dengan harapan kesalahan-kesalahan yang terjadi pada siklus I dapat diminimalkan.

\section{DESKRIPSI SIKLUS II}

\section{Perencanaan Tindakan}

Dalam penyusunan Rencana

Pelaksanaan Pembimbingan ( RPP ) pada siklus II ini masih mengacu dan melanjutkan semua jenis kegiatan pembimbingan pada siklus I. Menyiapkan alat, sumber, bahan yang diperlukan selama pelaksanaan pembimbingan dari pagi sampai sorelebih ditekankan pada hal-hal yang krusial dan harus ada pada saat pembimbingan. Kegiatan penyusunan instrumen pengamatan/observasi baik pengamatan pada kegiatan pembimbingan oleh observer yang berasal dari pengawas selaku pembimbing maupun penyusunan instrumenpengamatan/observasi

terbimbing oleh kepala sekolah selaku peneliti tentang jenis-jenis kegiatan guru peserta pembimbingan penyusunan proposal Penelitian Tindakan Kelas (PTK) masih mengacu pada instrumen pada siklus I. Pada prinsipnya sama tidak mengalami perubahan, yang disempurnakan hanyakesalahan tulis pada bagian subtansi masing-masing aspek yang diamati oleh observer.

Penyusunan pedoman analisis hasil observasi kepala sekolah maupun hasil observasi guru masih mengacu pada instrumen yang sudah disusun pada siklus I.

\section{Pelaksanaan Tindakan}

Proses pembimbingan lanjutan penyusunan proposal Penelitian Tindakan Kelas (PTK), dengan penekanan penyusunan Bab II tentang kajian pustaka dan $\mathrm{Bab}$ III tentang metode penelitian/prosedur penelitian. Kepala sekolah menjelaskan hal-hal yang penting yang terkait dengan kajian pustaka dan prosedur penelitian yang diselingi dengan tanya jawab dengan guru peserta pembimbingan dengan harapan kegiatan diskusi dan kerja kelompok nanti dapat berjalan lancar. Banyak pertanyaanpertanyaan dari peserta yang mengarah pada kajian pustaka dan prosedur penelitian, dan kepala sekolah selaku peneliti mampu menjawabnya dengan baik.

\section{Observasi/pengamatan pengumpulan data}

dan

Data hasil observasi kepala sekolah yang dilakukan oleh observer yaitu pengawas pembimbing, diperoleh skor rata-rata sebesar 4,22, Observasi guru memperoleh skor rata-rata sebesar 4,14 dan hasil kerja secara individual penyusunan proposal Penelitian Tindakan Kelas (PTK) yang dikerjakan dalam proses pembimbingan selama siklus I yang dilanjutkan diluar pembimbingan sebagai tugas ( PR ) diperoleh nilai ratarata sebesar 84,02.

\section{Refleksi}

Renungan hasil tindakan pada siklus II oleh kepala sekolah selaku peneliti hasilnya adalah bahwa tindakan pembimbingan penyusunan proposal PTK pada siklus ini mengalami kemajuan yang sangat berarti, hal ini bisa terjadi karena kepala sekolah memperhatikan hal-hal yang menjadi kendala yang dirasakan pada siklus sebelumnya dengan demikian tindakan pada siklus ini lebih dioptimalkan. Observasi kepala sekolah memperoleh skor rata-rata $(4,22)$, sementara hasil observasi guru memeperoleh skor rata-rata $(4,14)$, dan perolehan nilai rata-rata hasil penyusunan proposal PTK adalah $(84,02)$, serta hasil pengamatan pada saat presentasi antar kelompok memperoleh skor rata-rata $(4,50)$.

\section{PEMBAHASAN}

Siklus I

\section{Perencanaan Tindakan}

$$
\text { Peneliti menyusun Rencana }
$$

Pelaksanaan Pembimbingan (RPP), menyiapkan alat, sumber, bahan dan lainlain yang diperlukan dalam pelaksanaan pembimbingan, menyusun instrumen observasi kepala sekolah maupun 
observasi guru, dan menyusun pedoman analisis hasil observasi mengalami kendala, tetapi dapat diatasi dengan baik setelah meminta petunjuk kepada pengawas pembimbing.

\section{Pelaksanaan Tindakan}

Pada saat kepala sekolah selaku peneliti menyampaikan materi tentang tata cara penyusunan proposal Penelitian Tindakan Kelas (PTK) terdapat sedikit hambatan yaitu tingkat penyerapan peserta yang kurang seimbang. Faktor penyebabnya adalah karena ada guru yang sudah pernah membuat proposal PTK, dan ada guru yang belum sama sekali membuat proposal PTK. Solusinya adalah dengan dibentuknya kelompok besar, sehingga memudahkan dalam pembimbingan bagi guru yang masih kesulitan. Hasilnya semua peseta menjadi lebih dapat memahami dan bisa membuat draf proposal PTK walaupun masih belum sempurna.

Pada waktu pembimbingan dalam kelompok besar, terdapat kendala yaitu pada saat masih membimbing pada satu kelompok, kelompok lain juga sangat membutuhkan bimbingan. Hal ini terjadi karena masing-masing kelompok belum menunjuk teman sejawat yang dianggap mampu sebagai tutor sebaya. Setelah ditunjuk adanya tutor sebaya maka hambatan bisa diminimalkan. Pelaksanaan pembimbingan dan kerja kelompok yang dilaksanakan dengan model ini membawa hasil yang menggembirakan karena semua peserta pembimbingan merasa diperhatikan dan semua bisa bekerja dengan tenang penuh dengan semangat kekeluargaan, demokratis, inovativ, kreatif dan menyenangkan.

\section{Observasi/pengamatan dan pengumpulan data}

Perolehan skor rata-rata pada sklus I ini adalah $(3,56)$ ini artinya indikator keberhasilan belum tercapai. Hasilnya proses pembimbingan berjalan lancar dan hasil skor rata-rata yang diperoleh oleh 35 (tiga puluh lima) orang guru selama mengikuti pembimbingan adalah $(3,62)$ ini artinya belum memenuhi indikator keberhasilan yang telah diisyaratkan. Dari 35 (tiga puluh lima) orang peserta yang dinyatakan telah berhasil baru dua orang yaitu Rohani, S.Pd dengan perolehan nilai rata-rata $(88,46)$, dan Muhammad Idrus, S.Pd dengan perolehan nilai rata-rata $(94,62)$. Meskipun kedua guru itu sudah dinyatakan telah berhasil, masih perlu perbaikan agar dalam siklus II nanti nilainya lebih meningkat.

\section{Refleksi}

Hasil observasi kepala sekolah, hasil observasi guru, dan perolehan nilai rata-rata penyusunan proposal Penelitian Tindakan Kelas (PTK) secara berturutturut memperoleh hasil sebagai berikut : $(3,57)$, $(3,62)$, dan $(78,87)$. Hasil ini masih belum memenuhi indikator keberhasilan dimana untuk observasi kepala sekolah maupun observasi diharapkan memperoleh skor rata-rata $\geq$ 4,0 dan penyusunan proposal PTK diharapkan memperoleh nilai rata-rata $\geq$ 85,00 .

Dalam upaya melaksanakan jenis tindakan dalam upaya kegiatan tindak lanjut, kepala sekolah memberikan kesempatan untuk berkonsultasi diluar pembinaan secara klasikal yang dilaksanakan pada jam kerja dan atau diluar jam kerja sesuai kesepakatan antara kepala sekolahs selaku pembimbing dengan guru selaku terbimbing.

\section{Siklus II}

\section{Perencanaaan Tindakan}

Pada tahapan perencanaan tindakan ini yang kegiatannya meliputi ; 1) penyusunan Rencana Pembimbingan ( RPP ), 2) penyediaan alat, sumber bahan, 3) penyusunan lembar observasi, 4) menyusun pedoman analisa hasil observasi, dan 5) pembuatan jadwal kegiatan pembimbingan, pada prinsipnya sama dengan apa yang dilakukan pada siklus I. Penekanan pada kegiatan ini adalah perbaikan dan penyempurnaan 
kekurangan dan kesalahan yang pernah dilakukan pada siklus I. Secara umum hambatan tidak ada, begitupun faktor penyebabnya juga tidak ada, sehingga adalam penyusunan perencanaan tindakan pada siklus II berjalan sesuai dengan apa yang telah direncanakan.

\section{Pelaksanaan Tindakan}

Dalam pelaksanaan pembimbingan penyusunan proposal Penelitian Tindakan Kelas (PTK) mengalami sedikit hambatan yaitu tingkat kedisiplinan peserta khususnya ketepatan kehadiran masih belum sesuai dengan yang direncanakan. Faktor penyebabnya adalah ada beberapa guru yang kebetulan disekolahnya ada jam mengajar, sebagian besar guru yang demikian memberikan tugas terlebih dahulu baru menghadiri pembimbingan penyusunan proposal Penelitian Tindakan Kelas ( PTK). Solusi yang dilakukan oleh kepala sekolah selaku peneliti dengan mengundur waktu pelaksanaan tanpa mengurangi arti pentingnya pembimbingan. Hasilnya semua guru yang berjumlah 35 (tiga puluh lima) orang dapat hadir mengikuti pembimbingan.

Observasi/Pengamatan

dan

\section{Pengumpulan Data}

Pada kegiatan ini kepala sekolah memperoleh skor rata-rata $(4,22)$, smentara perolehan skor rata-ratahasil pengamatan kegiatan guru dalam kelompok adalah $(4,14)$ ini artinya kedua kegiatan itu sudah melampui indikator keberhasilan yang telah ditetapkan yaitu $\geq 4,0$. Sementara hasil nilai rata-rata dari penyusunan proposal adalah $(84,02)$, ini artinya ini artinya indikator keberhasilan $(85,00)$ belum tercapai. Sedangkan keberhasilan secara individual sejumlah 6 (enam) orang dari 35 (tiga puluh lima) orang yang mengikuti pembimbingan dalam penyusunan proposal PTK sudah berhasil dengan memperoleh presentase $17,14 \%$, ini artinya indikator keberhasilan yang menyatakan $\geq 10 \%$ peserta memperoleh nilai rata-rata $\geq 85,00$. Kenyataannya yang sudah memperoleh nilai rata-rata $\geq 85,00$ ada 6 (enam) orang. Artinya indikator keberhasilan telah tercapai.

Pada akhir pembimbingan diadakan presentasi tiap kelompok yang diwakili oleh salah satu anggota kelompok secara acak, hasilnya adalah kelompok guru yang mengajar di kelas VII memperoleh skor rata-rata $(4,25)$, kelompok guru yang mengajar di kelas VIII memperoleh skor rata-rata $(4,50)$, sedangkan kelompok guru yang mengajar di kelas IX memperoleh skor rata-rata $(4,75)$

\section{Refleksi}

Setelah selesaai siklus II kepala sekolah selaku peneliti diberikan beberapa saran dari observer antara lain : 1) proses pembimbingan sudah baik tetapi masih perlu ditingkatkan, 2) sebagian besar guru peserta pembimbingan sudah merasa senang dan bisa menerima materi serta dapat mempraktekkan secara langsung, tetapi mmasih ada 3 (tiga) orang peserta yang masih kelihatan kurang mengerti. Selanjutnya peneliti menganalisis data perolehan pada siklus II. Hasil observasi kepala sekolah memperoleh skor rata-rata $(4,22)$, hasil observasi guru memperoleh skor rata-rata $(4,14)$, sementara nilai ratarata hasil penyusunan proposal PTK $(84,02)$ dan yang terakhir skor rata-rat hasil presentasi kelompok $(4,50)$ kategori baik.

Dari perolehan skor dan nilai ratarata pada siklus II dinyatakan telah berhasil karena indikator keberhasilan telah dicapai.

Karena indikator keberhasilan sudah tercapai maka Penelitian Tindakan Sekolah (PTS) dengan judul : "Meningkatkan Kompetensi Guru SMPN 2 Wera Dalam Penyusunan Proposal Penelitian Tindakan Kelas (PTK) Melalui Bimbingan Kelompok Berbasis MGMP Tahun 2017/2018" dinyatakan telah "BERHASIL", maka Penelitian Tindakan Sekolah (PTS) dihentikan pada "SIKLUS II". 


\section{SIMPULAN}

Bimbingan kelompok berbasis MGMP sangat efektif dalam upaya meningkatkan kompetensi guru SMPN 2 Wera dalam penyusunan propsal Penelitian Tindakan Kelas (PTK). Hal ini dapat dibuktikan bahwa dalam proses pembimbingan penyusunan propsal Penelitian Tindakan Kelas (PTK) yang dilaksanakan sebanyak dua siklus telah mampu merubah kompetensi guru SMPN 2 Wera dengan data penguat sebagai berikut :

\begin{tabular}{|c|c|c|c|c|c|c|}
\hline & Jenis keggiatall & $\begin{array}{c}\text { Indikator' } \\
\text { keberlhsilan }\end{array}$ & $\begin{array}{c}\text { Siklus } \\
\text { I }\end{array}$ & Ket. & \begin{tabular}{|c} 
Siklus \\
II \\
\end{tabular} & Ket. \\
\hline & Observasikeppla selolah & 24,0 & 3,56 & Belum berhasil & 4,22 & Berhasil \\
\hline 6 & Observasi gunu & 24,0 & 3,62 & Belumberhasil & 4,14 & Berhasil. \\
\hline & Rata-rata klasikal & 285,00 & 78,87 & Belum bethasil & 84,02 & Bernasis \\
\hline 7 & \%individual & $285 \%$ & 5,71 & Belum berhasil & 17,14 & Berhass \\
\hline & \% kelompok & . & . & $\cdot$ & 4,50 & Ba \\
\hline
\end{tabular}

Indikator keberhasilan dalam Penelitian Tindakan Sekolah (PTS) ini pada siklus II sudah dapat dibuktikan ( sudah terbukti ), maka Penelitian Tindakan Sekolah (PTS) dengan judul "Meningkatkan Kompetensi Guru SMPN 2 Wera Dalam Penyusunan Proposal Penelitian Tindakan Kelas (PTK) Melalui Bimbingan Kelompok Berbasis MGMP Tahun 2017/2018" dinyatakan "BERHASIL", dan penelitian dihentikan pada siklus II.

\section{SARAN}

Kepada seluruh guru mata pelajaran SMPN 2 Wera diharapkan untuk melakukan Penelitian Tindakan Kelas (PTK) guna meningkatkan kualitas dan sumberdayaa manusia sebaagai guru yang profesional, handal dan terpercaya. Melalui Penelitian Tindakan Kelas (PTK) ini pula diharapkan kualitas proses pembelajaran di kelas senyatanya semakin menuju ke sistem pembelajaran yang aktif, inovatif, kreatif, efektif dan menyenangkan (PAKEM) yang pada gilirannya nanti prestasi belajar siswa dapat ditingkatkan secara signifikan.
Kepada seluruh kepala sekolah sejawat disarankan untuk melakukan Penelitian Tindakan Sekolah (PTS) dalam upaya meningkatkan profesionalisme sebagai kepala sekolah yang mamu membangun karakter guru yang menjadi tanggung jawab dalam wadah Musyawarah Guru Mata pelajaran (MGMP). Melalui Penelitian Tindakan Sekolah (PTS) ini pula diharapkan kepala sekolah mampu meningkatkan kompetensi guru dalam proses pembelajaran dikelas senyatanya, sehingga guru tampil sebagai sosok yang dapat mengaktifkan siswa selama proses pembelajaran di kelas senyatanya. Posisi kepala sekolah sebagai mitra kerja dengan guru binaannya diharapkan mampu memiliki jenis pendekatan, strategi dan metode yang tepat yang harus diterapkan oleh guru ketika tampil dikelas senyatanya yang mampu membelajarkan siswa yang aktif, kreatif, demokratif, dan pembentukan karakter bangsa oleh siswa di dalam kehidupan sehari-hari.

\section{DAFTAR PUSTAKA}

Anonim, 2016 dalam http://melshandyohayo.blogspot.com/2012/06/mgmpmusyawarah-gurumatapelajaran.html , diambil tanggal 10 Januari 2016 pukul 13.45 wita

Arikunto. S, 2006, Penelitian Tindakan Kelas, Jakarta : Bumi Aksara

Depdiknas, 2001, Kamus Besar Bahasa Indonesia, Jakarta : Balai Pustaka

Hartinah, S, 2009, Konsep Dasar Bimbingan Kelompok, Bandung : Pelita Aditama

Kementerian Nasional, 2011, Pedoman Kegiatan Pengembangan Keprofesian Berkelanjutan ( PKB), Jakarta : Direktorat Pembinaan Pendidik dan Tenaga Kependidikan Pendidikan Dasar

Kementrian Nasional, 2011, Buku Kerja Kepala sekolah Sekolah, Jakarta : Pusat PengembanganTenaga 
Kependidikan Badan Pengembangan Sumber Daya Manusia Pendidikan dan Penjaminan Mutu Pendidikan

Nana Sudjana, 2009, Penelitian Tindakan Kekepala sekolahan Konsep dan Aplikasinya Bagi Kepala sekolah Sekolah, Jakarta : LPP Bina Mitra

Suhardjono, 2006, Penelitian Tindakan Kelas Sebagai Kegiatan Pengembangan Profesi Guru, Jakarta : Bumi Aksara

Suhardjono, 2009, Melaksnakan Sekolah Sebagai Kegiatan Penelitian Tindakan Sekolah Sebagai Kegiatan Pengembangan Profesi Kepala sekolah Sekolah, Jakarta : Bumi Aksara

Suhardjono, dkk, 2012, Publikasi Ilmiah Dalam Kegiatan Pengembangan Keprofesian Berkelanjutan Bagi Guru, Jakarta : Cakrawala Indonesia

Syahrir. (2016). Pengembangan Perangkat Pembelajaran Matematika SMP untuk Meningkatkan Kemampuan Berfikir Kreatif. JIME. 2(1), 436441

Undang-Undang Nomor 14 Tahun 2005 Tentang Guru dan Dosen

Uzer Usman, 2001, Menjadi Guru Profesional, Bandung : Remaja Rasda Karya

Wiriatmadja, 2007, Metode Penelitian Tindakan Sekolah Sebagai Karya Tulis Ilmiah Dalam Kegiatan Pengembangan Proesi Kepala sekolah Sekolah, Jakarta : Dirjen PMPTK. 